\section{Preplant Monoammonium Phosphate Fertilizer and Compost Affects the Growth of Newly Planted 'Macoun' Apple Trees}

Renae E. Moran

Department of Animal and Horticultural Sciences, University of Maine, P.O. Box 179, Monmouth, ME 04259

James R. Schupp

Department of Horticultural Sciences, Hudson Valley Laboratory, Cornell University, Highland, NY 12528

Additional index words. Malus $\times$ domestica, flowering, vegetative growth, soil amendments

Abstract. 'Macoun'/Budagovsky 9 apple (Malus $\times$ domestica Borkh.) trees were planted in May 1998 in one of four preplant treatments that were soil incorporation of: 1) control, no phosphorus (P); 2) $90 \mathrm{~g}$ P per tree; 3) $128 \mathrm{~kg}$ compost per tree; and 4) $90 \mathrm{~g} \mathrm{P}$ and 128 kg compost per tree. Preplant addition of $P$ had no effect on soil organic matter, $P$, magnesium (Mg), and calcium (Ca) in the first three seasons after planting, but lowered soil potassium $(K)$ in the second season. Foliar nutrients, tree growth and flowering were also not affected by $P$. The addition of compost increased soil organic matter and $P$ in the first season after planting, and $\mathrm{pH}, \mathrm{K}, \mathrm{Mg}$, and $\mathrm{Ca}$ in the first three seasons. The addition of compost increased foliar nitrogen and $\mathrm{K}$ in all three seasons, and decreased foliar $\mathrm{Mg}$ in the first season. Compost incorporation increased shoot length in the first season, trunk cross-sectional area in the first two seasons, tree height and the number of growing points in third season, and flowering in the third and fourth seasons. Compost addition was more effective than $\mathbf{P}$ fertilization for increasing tree growth during the establishment years.

Replanting older orchards to high value apple cultivars is necessary for maintaining profitability, but is expensive. In order to obtain a quicker return on investment, growers plant high density orchards on precocious rootstocks to hasten production. In many orchards in the northeast, early yield is limited by tree growth, and trees are typically not cropped until the third or fourth season since tree growth is not optimal. Cropping is not permitted until a suitable framework is established. Since high early yield is associated with good tree growth during the establishment years (Forshey, 1988; Koch et al., 1980; Neilsen and Yorsten, 1991), cultural practices that encourage rapid tree growth will lead to greater early yield.

Two methods that have been used to increase early tree growth are the addition of phosphorous fertilizer or organic matter in the planting hole. Application of high rates of monoammonium phosphorus added at planting can increase tree vigor, flowering and early yield, particularly on replant sites (Bould and Parfitt, 1973; Neilsen et al., 1991; Taylor,

Received for publication 20 Aug. 2001. Accepted for publication 8 May 2002. Maine Agricultural and Forestry Experiment Station publication number 2559. We thank Bill Seekins and Bruce Hoskins for their technical assistance. Mention of a trademark, proprietary product, or vendor does not constitute a guarantee or warranty of the product, nor does it imply approval or disapproval to the exclusion of other products or vendors that may also be suitable.
1975; Taylor and Goubran, 1975; Williams and Thompson, 1979). Adding organic matter to the planting hole can also increase tree growth and flowering (Neilsen et al., 1991, 1994; Peryea and Covey, 1989). However, the effect of planting hole treatments on tree growth does not typically last beyond the first year, presumably because tree roots grow beyond the treated area (Autio et al., 1991; Nielsen et al., 1994). Soil incorporation of phosphorus $(\mathrm{P})$ or organic matter in a larger area may be one way to extend the benefit of planting treatments beyond the first year. The objective of this study was to determine if preplant soil incorporated MAP, compost, or MAP with compost can increase early growth and flowering of apple trees.

\section{Materials and Methods}

On 1 May 1998, ‘Macoun'/Bud.9 apple trees were planted into four preplant soil treatments. The four preplant soil treatments were: 1) no $\mathrm{P}$, as a control; 2) P fertilization; 3) compost; and 4) $\mathrm{P}$ and compost. Monoammonium phosphate (MAP, $11 \% \mathrm{~N}$ and $24 \% \mathrm{P}$ ) was applied at a rate of $373 \mathrm{~g}$ per tree. In order that each of the four treatment received an equivalent amount of nitrogen $(\mathrm{N})$ $(41 \mathrm{~g}$ per tree), urea $(46 \% \mathrm{~N})$ was applied at a rate of $89 \mathrm{~g}$ per tree to the control and the compost plots not receiving $\mathrm{P}$. The compost was applied and leveled to a uniform thickness of $10 \mathrm{~cm}$ and to a treated area $2.98 \mathrm{~m}^{2}$ per tree, so plots received $128 \mathrm{~kg}$ of compost, based on a bulk density of $563.7 \mathrm{~kg} \cdot \mathrm{m}^{-3}$. The compost was made from a mixture of 6 leaf litter : 2 apple pomace : 1 chicken manure (by volume). The leaves were a mixture of white pine needles, bigtooth aspen, quaking aspen, red maple, sugar maple, red oak, white birch, American beech and white ash. The chicken manure came from a deep-pit-cage layer operation and did not contain bedding. Wood ash was added at a rate of $0.13 \%$ on a volume basis to adjust the $\mathrm{pH}$ to 5.8 prior to composting. Temperature during the early stages of composting exceeded $71.1{ }^{\circ} \mathrm{C}$ and remained at or above $54.4{ }^{\circ} \mathrm{C}$ for $35 \mathrm{~d}$. The compost contained $1.09 \%$ total N, $0.47 \% \mathrm{P}, 0.74 \% \mathrm{~K}$, a final $\mathrm{pH}$ of 7.8 (after composting), and an electrical conductivity (EC) of $11.3 \mathrm{mS} \cdot \mathrm{cm}^{-1}$. Electrical conductivity and $\mathrm{pH}$ were measured according to the methods of Warnke (1986). In lateApr. 1998, preplant treatments were applied to strips of killed sod that were $1.22 \mathrm{~m}$ wide $\times$ $7.32 \mathrm{~m}$ long. MAP or urea was then broadcast over plots. All plots were rototilled to a depth of $15 \mathrm{~cm}$ until thoroughly incorporated. The pretreatment soil properties are shown in Table 1. The soil was a Dixfield fine sandy loam, coarse-loamy, mixed frigid typic Haplothords. Each plot consisted of three trees at a spacing of $1.8 \mathrm{~m}$ between trees and $5.5 \mathrm{~m}$ between rows. 'Cortland'/M.26 trees were planted as a buffer between each plot. At planting, trees were headed to a height of $70 \mathrm{~cm}$ aboveground and attached to a galvanized conduit stake. The two buds directly below the new leader were rubbed off, as well as, buds that were on the lower $38 \mathrm{~cm}$ of the tree. After planting, all plots were sprayed with orysalin herbicide at a rate of $9.35 \mathrm{~L} \cdot \mathrm{ha}^{-1}$, and glyphosate was applied at a rate of in $23.5 \mathrm{~mL} \cdot \mathrm{L}^{-1}$ in May and June with a hand-held wand to control perennial weeds. Pests and diseases were controlled as needed. The study was conducted in an area that was previously planted to apples. Trees were not fertilized after planting in order to determine the residual effects of compost and P.

Leaf and soil samples were collected from each plot in late July. A soil sample was collected from each tree to a depth of $15 \mathrm{~cm}$ and pooled as one sample per plot. Twenty-five midshoot leaves were collected from each plot. Leaves were washed, rinsed three times in distilled water, and dried at $70{ }^{\circ} \mathrm{C}$. Soil was analyzed for $\mathrm{Pand}$ organic matter in the first season, and for $\mathrm{K}, \mathrm{Ca}, \mathrm{Mg}$, and $\mathrm{pH}$ every year. Leaves were analyzed for N, P, K, Ca, Mg, B, Zn, Mn, $\mathrm{Cu}$, and $\mathrm{Fe}$. Total $\mathrm{N}$ was determined using the Dumas standard combustion method modified by Sweeney (1989). All other nutrients were measured by dry ashing (Chapman and Pratt, 1961). Solution analysis was by plasma emission. Soil $\mathrm{pH}$ was measured in distilled water. Nutrients were extracted in neutral ammonium acetate using the modified Morgan extraction procedure (Morgan, 1941). Effective CEC was calculated by summing milliequivalents of $\mathrm{Ca}$, $\mathrm{K}$, and $\mathrm{Mg}$. Soil organic matter was measured using the loss-of-weight-on-ignition method (Ball, 1964; Walkey-Black, 1934).

Vegetative growth was measured at the end of each growing season in November after leaf fall. Trunk diameter was measured at $25 \mathrm{~cm}$ 
Table 1. Orchard soil properties ${ }^{2}$ before and in the three seasons after soil incorporation of monoammonium phosphate (MAP) or compost for planting and growing 'Macoun' apple trees.

\begin{tabular}{|c|c|c|c|c|c|c|c|c|}
\hline \multicolumn{2}{|c|}{ Treatment } & \multirow[b]{2}{*}{$\mathrm{pH}$} & \multirow[b]{2}{*}{$\begin{array}{c}\mathrm{OM} \\
\left(\mathrm{g} \cdot \mathrm{kg}^{-1}\right)\end{array}$} & \multirow[b]{2}{*}{$\begin{array}{c}\mathrm{P} \\
\left(\mathrm{kg} \cdot \mathrm{ha}^{-1}\right)\end{array}$} & \multirow[b]{2}{*}{$\begin{array}{c}\mathrm{K} \\
\left(\mathrm{kg}^{-} \cdot \mathrm{ha}^{-1}\right)\end{array}$} & \multirow[b]{2}{*}{$\underset{\left(\mathrm{kg} \cdot \mathrm{ha}^{-1}\right)}{\mathrm{Mg}}$} & \multirow[b]{2}{*}{$\underset{\left(\mathrm{kg} \cdot \mathrm{ha}^{-1}\right)}{\mathrm{Ca}}$} & \multirow[b]{2}{*}{$\begin{array}{c}\text { CEC } \\
(\mathrm{me} / 100 \mathrm{~g})\end{array}$} \\
\hline $\begin{array}{l}\text { Compost } \\
\text { (kg/tree) }\end{array}$ & $\begin{array}{c}\mathrm{P} \\
(\mathrm{g} / \text { tree })\end{array}$ & & & & & & & \\
\hline \multicolumn{9}{|c|}{ Pretreatment } \\
\hline None & None & 6.8 & 47 & 10.9 & 235 & 384 & 2664 & 7.6 \\
\hline \multicolumn{9}{|c|}{$1^{\text {st }}$ season } \\
\hline 0 & 0 & 6.4 & 45 & 11.1 & 235 & 342 & 2950 & 6.9 \\
\hline 0 & 90 & 6.4 & 44 & 14.6 & 221 & 353 & 2861 & 6.8 \\
\hline 128 & 0 & 6.9 & 53 & 89.2 & 584 & 591 & 5579 & 11.1 \\
\hline 128 & 90 & 6.8 & 56 & 97.3 & 534 & 574 & 5489 & 10.4 \\
\hline \multicolumn{9}{|l|}{ Significance } \\
\hline $\mathrm{P}$ & & NS & NS & NS & NS & NS & NS & NS \\
\hline Compost & & $* *$ & $* *$ & $* *$ & $* * *$ & $* *$ & $* * *$ & $* * *$ \\
\hline $\mathrm{P} \times$ compost & & NS & NS & NS & NS & NS & NS & NS \\
\hline \multicolumn{9}{|c|}{$2^{\text {nd }}$ season } \\
\hline 0 & 0 & 6.8 & & & 278 & 313 & 2252 & 6.5 \\
\hline 0 & 90 & 6.7 & & & 263 & 336 & 2315 & 6.7 \\
\hline 128 & 0 & 7.0 & & & 522 & 460 & 3354 & 9.8 \\
\hline 128 & 90 & 6.9 & & & 554 & 477 & 3386 & 10.0 \\
\hline \multicolumn{9}{|l|}{ Significance } \\
\hline $\mathrm{P}$ & & * & & & NS & NS & NS & NS \\
\hline Compost & & $*$ & & & $* * *$ & $* *$ & $* * *$ & $* * *$ \\
\hline $\mathrm{P} \times$ compost & & NS & & & NS & NS & NS & NS \\
\hline \multicolumn{9}{|c|}{$3^{\text {rd }}$ season } \\
\hline 0 & 0 & 6.7 & & & 107 & 167 & 1239 & 7.0 \\
\hline 0 & 90 & 6.8 & & & 91 & 182 & 1272 & 7.2 \\
\hline 128 & 0 & 7.2 & & & 158 & 231 & 1828 & 10.2 \\
\hline 128 & 90 & 7.0 & & & 138 & 210 & 1698 & 9.4 \\
\hline \multicolumn{9}{|l|}{ Significance } \\
\hline $\mathrm{P}$ & & NS & & & $* * *$ & NS & NS & NS \\
\hline Compost & & $*$ & & & $* * *$ & * & $* * *$ & $* * *$ \\
\hline $\mathrm{P} \times$ compost & & NS & & & NS & NS & NS & NS \\
\hline
\end{tabular}

${ }^{2}$ Nutrients were extracted in neutral ammonium acetate using the modified Morgan extraction procedure. Effective CEC was calculated by summing milliequivalents of $\mathrm{Ca}, \mathrm{K}$, and $\mathrm{Mg}$. Soil organic (OM) matter was measured using the loss-of-weight-on-ignition method.

Ns, $* * *, * * *$ Nonsignificant, or significant at $P \leq 0.05,0.01$, or 0.001 , respectively.

above the graft union. Total current season shoot growth was measured as the combined length of all shoots and spurs at least $1 \mathrm{~cm}$ in length. The total number of shoots and spurs at least $1 \mathrm{~cm}$ in length was also counted each year, and in the third season, spurs that were $0.5 \mathrm{~cm}$ in length were also included. Tree height was measured the third season. In the second season, the number of flower clusters was counted on each tree just before full bloom. In third and fourth seasons, the number of flower clusters borne on either shoots or spurs $(<10 \mathrm{~cm}$ long) was counted. In the first three seasons, all flower clusters were removed after counting. In the fourth season, 12 June 2001, trees were hand-thinned to five fruit per $\mathrm{cm}^{2}$ trunk cross-sectional area after counting.

The experiment was a split-plot design with compost as the main plot and $\mathrm{P}$ fertilizer as the subplot. Each treatment was replicated six times. Data were subjected to analysis of variance using general linear method procedures of SAS (SAS Institute 2000, Cary, N.C.). Trunk cross-sectional area at planting was used as a covariate to adjust for differences in initial tree size.

\section{Results}

Soil fertility was influenced by the addition of compost, but not significantly by the addition of $\mathrm{P}$ (Table 1). The addition of compost with or without $\mathrm{P}$ resulted in a higher soil $\mathrm{pH}$ in each of the three seasons after planting compared to plots without compost. There was no effect of $\mathrm{P}$ fertilization on soil $\mathrm{pH}$ in the first or third season. In the second season after planting, preplant $\mathrm{P}$ lowered soil $\mathrm{pH}$ when compared to plots that received no P. This difference in $\mathrm{pH}$ in the second season was smaller than the precision of the measurements ( \pm 0.1 units) and may not have been a real difference. The addition of Phad no effect on soil organic matter or soil $\mathrm{P}$, but compost increased both in the first season. Soil K was decreased by $\mathrm{P}$ in the third season after planting. Compost increased soil $\mathrm{K}$ in all three seasons of the study. Soil $\mathrm{Mg}$, $\mathrm{Ca}$, and $\mathrm{CEC}$ were unaffected by P. Compost increased all three in each season of the study compared to plots without compost. There was no interaction between compost and $\mathrm{P}$ on soil $\mathrm{pH}$ or soil fertility.

Foliar nutrient status was affected by compost, but not $\mathrm{P}$ (Table 2). The addition of $\mathrm{P}$ did not affect leaf N, P, K, Ca, or Mg. Compost increased leaf $\mathrm{N}$ and $\mathrm{K}$ compared to trees in plots without compost in all three seasons after planting. Leaf $\mathrm{P}$ and $\mathrm{Ca}$ were not affected by compost. Compost decreased leaf Mg in the first season after planting, but had no effect in the second or third season. There was no interaction between compost or P fertilizer on leaf macronutrients. Of the micronutrients measured, only $\mathrm{Cu}$ was affected by preplant treatments with a significant interaction between P fertilizer and compost in 1998. Addition of $\mathrm{P}$ decreased leaf $\mathrm{Cu}$, but only when added with compost $(3.8$ $\left.\mathrm{mg} \cdot \mathrm{kg}^{-1}\right)$. This difference was $<1 \mathrm{mg} \cdot \mathrm{kg}^{-1}$ and probably not physiologically significant. Leaf $\mathrm{B}, \mathrm{Fe}, \mathrm{Mn}$, and $\mathrm{Zn}$ were not affected by any of the preplant treatments (data not shown).

Tree growth was favored by compost, but not by $\mathrm{P}$ fertilization. TCA was not affected by $\mathrm{P}$ in any season of the trial (Table 3 ). Compost increased TCA in the first two seasons, but not in the third season. Addition of $\mathrm{P}$ had no significant effect on current season shoot growth including spurs in any season of the study. Annual shoot growth was increased by compost in the first season, but not significantly in the second or third season. The number of growing points per tree was not affected by $\mathrm{P}$ in any season. Compost increased the number of growing points in the third season, but not in the first or second seasons. Tree height, measured in the third season, was increased by compost, but not by P. The total number of flower clusters per tree in the second season was not affected by any of the treatments. In the third and fourth seasons, the number of flower clusters borne on spurs $(10 \mathrm{~cm}$ or less in length) was increased by compost, but not affected by P. The number of flower clusters that occurred on shoots greater than $10 \mathrm{~cm}$ in length was not affected by any of the treatments. There was no interaction between $P$ fertilizer and compost for any of the growth parameters measured.

\section{Discussion}

Our goal was to improve the growth of newly planted apple trees with preplant soil amendments in order to increase early yield. Shoot growth was increased by preplant incorporated compost in the first season, TCA in the first two seasons and tree height in the third. This was similar to other findings in which organic matter added to the planting hole increased shoot growth and trunk girth (Autio et al., 1991; Neilsen, et al., 1994). The effect of planting hole treatments was no longer evident by the second or third season, and this was attributed to roots growing beyond the planting hole (Autio et al., 1991). In our study, the effect of soil incorporated organic matter on trunk circumference and shoot growth also diminished with time. The diminished effect was possibly due to the depletion of soil K, $\mathrm{Mg}$, and $\mathrm{Ca}$. Soil $\mathrm{K}$ in the compost plots was twice as great as in noncompost plots, but this difference was much smaller by the third season. Although, trunk and shoot growth differences diminished with time, the increase in tree height and number of growing points was evident in the third season indicating that the cumulative effect of compost on tree size was not short-lived.

Compost increased flowering in the third and fourth season. This is in agreement with a previous study in which organic matter added to the planting hole increased flowering (Neilsen, et al., 1994). In our study, the increase in flowering occurred only on spurs. Flowering on shoots longer than $10 \mathrm{~cm}$ was not significantly 
Table 2. Effect of preplant soil-incorporated monoammonium phosphate (MAP) or compost on 'Macoun' apple foliar nutrients in the first three seasons after planting.

\begin{tabular}{|c|c|c|c|c|c|c|c|}
\hline \multicolumn{2}{|c|}{ Treatment } & \multicolumn{5}{|c|}{ Dry wt $\left(\mathrm{mg} \cdot \mathrm{g}^{-1}\right.$ dry wt) } & \multirow{2}{*}{$\frac{\mathrm{Cu}}{\left(\mathrm{mg} \cdot \mathrm{kg}^{-1} \text { dry wt }\right)}$} \\
\hline Compost (kg/tree) & $\mathrm{P}(\mathrm{g} /$ tree $)$ & $\mathrm{N}$ & $\mathrm{P}$ & $\mathrm{K}$ & $\mathrm{Ca}$ & $\overline{\mathrm{Mg}}$ & \\
\hline \multicolumn{8}{|c|}{$1^{\text {st }}$ season } \\
\hline 0 & 0 & 26.4 & 1.8 & 14.2 & 7.9 & 3.4 & 4.0 \\
\hline 0 & 90 & 26.4 & 1.9 & 14.3 & 8.3 & 3.5 & 4.3 \\
\hline 128 & 0 & 28.4 & 1.9 & 20.9 & 8.0 & 3.2 & 4.4 \\
\hline 128 & 90 & 28.5 & 1.9 & 20.5 & 7.9 & 3.0 & 3.8 \\
\hline \multicolumn{8}{|l|}{ Significance } \\
\hline $\mathrm{P}$ & & $\mathrm{NS}^{\mathrm{Z}}$ & NS & NS & NS & NS & NS \\
\hline Compost & & $* *$ & NS & $* * *$ & NS & $*$ & NS \\
\hline $\mathrm{P} \times$ compost & & NS & NS & NS & NS & NS & $*$ \\
\hline \multicolumn{8}{|c|}{$2^{\text {nd }}$ season } \\
\hline 0 & 0 & 23.9 & 1.6 & 15.4 & 11.4 & 2.5 & 7.5 \\
\hline 0 & 90 & 23.2 & 1.6 & 15.1 & 11.3 & 2.7 & 7.2 \\
\hline 128 & 0 & 24.1 & 1.7 & 18.0 & 10.7 & 2.5 & 7.9 \\
\hline 128 & 90 & 24.2 & 1.6 & 18.3 & 10.9 & 2.5 & 6.7 \\
\hline \multicolumn{8}{|l|}{ Significance } \\
\hline $\mathrm{P}$ & & NS & NS & NS & NS & NS & NS \\
\hline Compost & & $*$ & NS & $*$ & NS & NS & NS \\
\hline $\mathrm{P} \times$ compost & & NS & NS & NS & NS & NS & NS \\
\hline \multicolumn{8}{|c|}{$3^{\text {rd }}$ season } \\
\hline 0 & 0 & 22.0 & 1.6 & 13.1 & 15.9 & 2.1 & 14 \\
\hline 0 & 90 & 21.7 & 1.6 & 13.3 & 15.4 & 2.2 & 13 \\
\hline 128 & 0 & 22.8 & 1.7 & 14.1 & 15.8 & 2.2 & 13 \\
\hline 128 & 90 & 22.4 & 1.8 & 14.6 & 15.4 & 2.1 & 14 \\
\hline \multicolumn{8}{|l|}{ Significance } \\
\hline $\mathrm{P}$ & & NS & NS & NS & NS & NS & NS \\
\hline Compost & & $*$ & NS & $*$ & NS & NS & NS \\
\hline $\mathrm{P} \times$ compost & & NS & NS & NS & NS & NS & NS \\
\hline
\end{tabular}

Table 3. Effect of preplant soil-incorporated monoammonium phosphate (MAP) or compost on 'Macoun' apple tree growth in the first three seasons after planting, and flowering in the second, third and fourth seasons after planting.

\begin{tabular}{|c|c|c|c|c|c|c|}
\hline \multicolumn{2}{|c|}{ Treatment } & \multirow[b]{2}{*}{$\begin{array}{l}\mathrm{TCA}^{\mathrm{z}} \\
\left(\mathrm{cm}^{2}\right)\end{array}$} & \multirow{2}{*}{$\begin{array}{c}\text { Total shoot } \\
\text { length } \\
(\mathrm{cm})\end{array}$} & \multirow{2}{*}{$\begin{array}{c}\text { Growing } \\
\text { points } \\
\text { (no./tree) }\end{array}$} & \multirow{2}{*}{$\begin{array}{c}\text { Tree } \\
\text { height } \\
(\mathrm{cm})\end{array}$} & \multirow{2}{*}{$\begin{array}{c}\text { Spur flower } \\
\text { clusters } \\
\text { (no./tree) }\end{array}$} \\
\hline $\begin{array}{l}\begin{array}{l}\text { Compost } \\
\text { (kg/tree) }\end{array} \\
\end{array}$ & $\begin{array}{c}\mathrm{P} \\
(\mathrm{g} / \text { tree })\end{array}$ & & & & & \\
\hline & & & $1^{\text {st }}-2^{\text {nd }}$ season & & & \\
\hline 0 & 0 & 1.2 & 106 & 6 & & 7 \\
\hline 0 & 90 & 1.4 & 113 & 6 & & 7 \\
\hline 128 & 0 & 1.5 & 125 & 6 & & 10 \\
\hline 128 & 90 & 1.4 & 125 & 7 & & 12 \\
\hline \multicolumn{7}{|l|}{ Significance } \\
\hline $\mathrm{P}$ & & $\mathrm{NS}^{\mathrm{y}}$ & NS & NS & & NS \\
\hline Compost & & * & * & NS & & NS \\
\hline $\mathrm{P} \times$ compost & & NS & NS & NS & & NS \\
\hline & & & $2^{n d}-3^{r d}$ season & & & \\
\hline 0 & 0 & 1.8 & 148 & 27 & & 35 \\
\hline 0 & 90 & 2.0 & 168 & 27 & & 36 \\
\hline 128 & 0 & 2.2 & 195 & 27 & & 40 \\
\hline 128 & 90 & 2.2 & 186 & 28 & & 42 \\
\hline \multicolumn{7}{|l|}{ Significance } \\
\hline $\mathrm{P}$ & & NS & NS & NS & & NS \\
\hline Compost & & $*$ & NS & NS & & $*$ \\
\hline $\mathrm{P} \times$ compost & & NS & NS & NS & & NS \\
\hline & & & $3^{\text {rd }}-4^{\text {th }}$ season & & & \\
\hline 0 & 0 & 4.1 & 426 & 59 & 176 & 63 \\
\hline 0 & 90 & 4.2 & 376 & 68 & 175 & 64 \\
\hline 128 & 0 & 4.7 & 454 & 80 & 190 & 77 \\
\hline 128 & 90 & 4.5 & 420 & 75 & 191 & 75 \\
\hline \multicolumn{7}{|l|}{ Significance } \\
\hline $\mathrm{P}$ & & NS & NS & NS & NS & NS \\
\hline Compost & & NS & NS & $* *$ & $* *$ & * \\
\hline $\mathrm{P} \times$ compost & & NS & NS & NS & NS & NS \\
\hline
\end{tabular}

${ }^{2}$ Trunk cross-sectional area (TCA) was adjusted for initial TCA at planting by covariate analysis. Flower clusters were counted in the spring of the following season on spurs $(<10 \mathrm{~cm}$ in length) and shoots in the second season, and on spurs in the third and fourth seasons.

Ns, ${ }^{*}, * *$ Nonsignificant, or significant at $P \leq 0.05$ or 0.01 , respectively. increased by compost. It is not known if the increase in tree size in our study was large enough to increase early yield since the trees did not attain a size large enough to permit cropping until after the third growing season. The trees in this study were on Bud.9 rootstock, which is less vigorous than M.9 EMLA (NC140, 1996), and may be insufficiently vigorous for northern New England.

Compost increased tree growth and flowering most likely by improving soil fertility and tree nutrient status. Compost increased soil organic matter which probably increased $\mathrm{N}$ supply to the trees. A previous study indicated that peat added to the planting hole increased tree growth without increasing foliar $\mathrm{N}$ as a result of dilution (Peryea and Covey, 1989). In our study, compost improved both tree growth, and $\mathrm{N}$ and $\mathrm{K}$ status of leaves. However, differences in leaf $\mathrm{N}$, due to compost, diminished with time and were probably not large enough to affect tree growth in the second or third season. For compost plots, the level of foliar $\mathrm{N}$ in the first season was higher than optimum for nonbearing trees and within the optimum range in plots without compost (Stiles and Reid, 1991). Levels of $\mathrm{N}$ decreased to at or just below the optimum in the second season. Compost addition more than doubled the level of soil K, compared to plots without compost, which led to greater levels of foliar K. In the compost plots, foliar K was just above optimum the first season, and within the optimum range the second and third seasons. Plots without compost were within the optimum range the first two seasons, but fell slightly below this in the third season. The level of soil $\mathrm{K}$ in the third season was lower in plots that received $\mathrm{P}$. It is not clear why this occurred since foliar $\mathrm{K}$ and tree growth were unaffected by P. Compost also increased soil $\mathrm{Mg}$ and $\mathrm{Ca}$, but this did not lead to increased foliar levels of these elements. Instead, leaf $\mathrm{Mg}$ was slightly lower and leaf $\mathrm{Ca}$ was unaffected in plots that received compost. The large increase in soil $\mathrm{K}$ following compost incorporation may have interfered with $\mathrm{Ca}$ and $\mathrm{Mg}$ uptake, so that even though soil $\mathrm{Ca}$ and $\mathrm{Mg}$ were greater, foliar levels were not. For all treatments, levels of foliar $\mathrm{Mg}$ were in the low range the season of planting and decreased to deficient levels in the third season. Levels of foliar Cawere low the first season, but increased to a sufficient level by the second season and remained sufficient in the third season. The soil level of $\mathrm{P}$ was within the optimum range before treatment, but was increased to above optimum by compost. Although the level of $\mathrm{P}$ in the soil was increased with compost, there was no increase in foliar P. High levels of P can inhibit uptake of Zn (Stiles and Reid, 1991), but levels of foliar $\mathrm{Zn}$ were not affected by compost. Foliar $\mathrm{Zn}$ was within the optimum range in the first two seasons, but was low in the third season for all treatments. Pretreatment soil $\mathrm{pH}$ was slightly above the optimum range of 6.0 to 6.5 for apple. Soil acidification occurred in the first season compared to the pretreatment soil $\mathrm{pH}$ in plots that did not receive compost. Addition of compost increased soil $\mathrm{pH}$ to near neutrality. Increasing soil $\mathrm{pH}$ can limit availability of $\mathrm{Mn}$ and decrease leaf 
levels in apple (Neilsen et al., 1993), but this did not occur in our study. Typical of Maine orchards, Mn was in the low range in the first two seasons and became deficient in the third season in all plots.

In addition to soil fertility, organic matter can improve soil water-holding capacity and soil aeration. An increase in the water-holding capacity of the soil would have been advantageous in the first season, when the newly planted trees were generating new roots to replace those lost in transplanting, and in the second season, in which little precipitation occurred before September. The increase in foliar $\mathrm{N}$ and $\mathrm{K}$ with compost may have been due to increased water-holding capacity of the soil that occurs with greater organic matter content. Compost may have increased tree growth and nutrient status through its effect on water relations, but this was not measured.

Preplant incorporation of $\mathrm{P}$ fertilizer had no effect on tree growth or flowering. In a previous report, the increase in tree growth following $\mathrm{P}$ fertilization did not occur in all orchards that were tested indicating that the effect of $\mathrm{P}$ fertilization is site specific (Neilsen and Yorsten, 1991; Neilsen et al., 1994). P fertilization can increase flowering (Bould and Parfitt, 1973; Taylor, 1975; Williams and Thompson, 1979) when associated with greater leaf P (Neilsen et al., 1990). In our study, $\mathrm{P}$ fertilization did not affect the $\mathrm{P}$ status of the trees, and is most likely why $\mathrm{P}$ fertilization had little effect on tree growth and flowering.

The results of this study indicate that preplant compost incorporation was more effective than $\mathrm{P}$ fertilization for increasing tree growth during the establishment years. The practice of adding P to the planting hole may not be appropriate for all sites, particularly those with high levels of $\mathrm{P}$ present before planting.
Soil incorporation of compost increased tree growth and flowering into the third year after planting. Greater tree growth with compost was most likely due to improved $\mathrm{N}$ and $\mathrm{K}$ status of the trees, soil aeration and water-holding capacity. Trees planted in soil amended with compost would potentially fill their space more quickly and be able to support more fruit growth in the first years of cropping.

\section{Literature Cited}

Autio, W.R., D.W. Greene, D.R. Cooley, and J.R. Schupp. 1991. Improving the growth of newly planted apple trees. HortScience 26:840-843.

Ball,D.F. 1964. Loss-on-ignition as an estimate of organic matter and organic carbon in noncalcareous soils. J. Soil Sci. 15:84-92.

Bould, C. and R.I. Parfitt. 1973. Leaf analysis as a guide to the nutrition of fruit crops. X. Magnesium and phosphorus sand culture experiments with apple. J. Sci. Food. Agr. 24:175-185.

Chapman, H.D. and P.F. Pratt. 1961. Methods of analysis for soils, plants and waters. Univ. California-Berkeley, Div. of Agr. Sci., p. 60.

Forshey, C.G. 1988. Care and training of young apple trees. New England Fruit Mtg. Proc. 94: 98-102.

Koch, B.L., R.L. Covey, and W. Haglund. 1980. Effect of soil fumigation on the early growth and production of 'Delicious' apple trees. J. Amer. Soc. Hort. Sci. 105:887-890.

Morgan, M.F. 1941. Chemical soil diagnosis by the universal soil testing system. Connecticut Agr. Expt. Sta. Bul. 450.

NC-140. 1996. Rootstock and scion cultivar interact to affect apple tree performance: A five-year summary of the $1990 \mathrm{NC}-140$ cultivar/rootstock trial. Fruit Var. J. 50:175-187.

Neilsen, G.H. and J. Yorston. 1991. Soil disinfection and monoammonium phosphate fertilization increase precocity of apples on replant problem soils. J. Amer. Soc. Hort. Sci. 116:651-654.

Neilsen, G.H., E.J. Hogue, and P. Parchomchuk.
1990. Flowering of apple trees in the second year is increased by first-year P fertilization. HortScience 25:1247-1250.

Neilsen, G.H., J. Beulah, E.J. Hogue, and R.S. Utkhede. 1991. Use of greenhouse seedling bioassays to predict first year growth of apple trees planted in old orchard soil. HortScience 26:1383-1386.

Neilsen, G.H., P. Parchomchuk, W.D. Wolk, and O.L. Lau. 1993. Growth and mineral composition of newly planted apple trees following fertigation with $\mathrm{N}$ and P. J. Amer. Soc. Hort. Sci. 118:50-53.

Neilsen, G.H., J. Beulah, E.J. Hogue, and R.S. Utkhede. 1994. Planting-hole amendments modify growth and fruiting of apples on replant sites. HortScience 29:82-84.

Peryea, F.J. and R.P. Covey. 1989. Replant management strategies influence early growth of apple trees in a sand soil. HortScience 24:947-949.

Stiles, W.C. and W.S. Reid. 1991. Orchard nutrition management. Cornell Coop. Ext. Info. Bul. 219.

Sweeney, R.A. 1989. Generic combustion method for determination of crude protein in feeds: Collaborative study. J. Assn. Offic. Anal. Chem. 72: 770-774.

Taylor, B.K. 1975. Response of newly planted peach and apple trees to superphosphate. Austral. J. Agr. Res. 26:521-528.

Taylor, B.K. and F.H. Goubran. 1975. The phosphorus nutrition of the apple tree. I. Influence of rate of superphosphate on the performance of young trees. Austral. J. Agr. Res. 26:843-853.

Walkley, A. and I.A. Black. 1934. An examination of Degtjareff method for determining soil organic matter and a proposed modification of the chromic acid titration method. Soil Sci. 37:29-37.

Warnke, D.D. 1986. Analyzing greenhouse growth media by saturation extract method. HortScience 21:223-225.

Williams, J.M. and A.H. Thompson. 1979. Effect of phosphorus, nitrogen, and daminozide on growth and first fruiting of dwarf apple trees. HortScience 14:703-704. 